\title{
6 Digital sleeper cells and the ethics of risk management
}

\author{
Kevin Macnish
}

\section{Introduction}

The advent of networked systems has brought with it new opportunities in intelligence, giving rise to a sub-species of "cyberintelligence". One such opportunity is that of what I refer to here (for want of a better term) "digital sleeper cells". These consist in code which can be placed on an adversary's network and left dormant for a period of time, before being activated if, and when, needed. There is limited written evidence of such cells existing, the most famous being that used on the Ivano-Frankivsk power network in 2015 (Lehman 2016), but anecdotal evidence suggests that the Ivano-Frankivsk case was not an anomaly.

Such new opportunities bring with them new risks, including ethical risks. This calls for intelligence ethics to expand to include cyberintelligence and with it the ethical debate to similarly expand. The problem, as I argue in the following, is that traditional ethical frameworks for intelligence, and particularly the notion of jus ad intelligentia/in intelligentium, are often insufficiently granular to provide ethical guidance in cases of uncertainty. Whereas traditional (analogue?) intelligence has centuries of case studies to draw on, the new ethical issues arising in cyberintelligence have no historical analogies.

In this chapter, I argue that a way forward in developing an ethics of cyberintelligence, at least insofar as consideration of proportionality is to play a role, is to consider likely reciprocity. I explore this through an analysis of the aforementioned digital sleeper cells. Following an introduction to some of the challenges facing intelligence ethics in the digital, networked age, I consider the nature and role of digital sleeper cells and how they are likely to be perceived by those using them and by those affected by them. I then suggest that the recently developed ethics of risk literature can inform and guide ethical intelligence activities through their ability to highlight complicating factors which may otherwise be overlooked.

It is important to note that in this chapter I am not suggesting that any current or former intelligence agencies are being cavalier in their use of digital sleeper cells. From private conversations, the impression given is that the use of these tools, at least in liberal democracies, is extremely limited and carefully controlled. While some may be willing to take such reassurances on trust, many will not, especially in light of intelligence scandals such as reportedly "sexed up" dossiers being used

DOI: $10.4324 / 9781003164197-9$ 
by politicians to justify going to war (Herring and Robinson 2014; Humphreys 2005). Furthermore, while we may currently have morally trustworthy intelligence chiefs in post, it would be complacent to presume that this will always be the case. I am hence not writing in critique of any one state or agency, still less any individuals. I am, though, writing with an eye clearly on the future moral health of the intelligence community.

\section{Intelligence ethics}

There are a number of ways, theories and frameworks through which we can approach intelligence ethics. If intelligence is about finding out, or trying to find out, information that we do not already know, then intelligence ethics is about discovering this information in an ethical manner. As such, there are a number of standard normative frameworks that can be applied to intelligence ethics. I have argued elsewhere (Macnish 2017, 78-82) that, at the very least, we can think about intelligence ethics from a deontological perspective, a consequentialist perspective, a virtue ethics perspective or a reciprocity perspective. Each of these has its respective advocates and dissenters. However, I also believe that one of the most promising frameworks for understanding intelligence ethics is that of the just war tradition. This approach has been promoted by Michael Quinlan, David Omand, Ross Bellaby and myself at different times in the past (Bellaby 2014; Macnish 2017; Omand 2011; Quinlan 2007). The just war tradition carries the advantage of a combination of both deontological and consequential thinking, coupled with a rich tradition of philosophical reflection and case studies.

One challenge to using the just war tradition in thinking about intelligence ethics is that, while the aforementioned historical tradition is indeed rich and varied, it has only recently started to be applied to intelligence ethics. As such, there are far fewer cases or arguments from which to draw when one comes to specifically intelligence-related problems. The just war tradition is therefore a valuable framework through which to understand established ethical problems, but it is far weaker when it comes to determining what to do in scenarios with new and emerging technologies. For example, we can agree that there is strong rationale for thinking that any intelligence activity should be proportionate in terms of the harms that it risks when balanced against the benefits that it promises. However, proportionality is notoriously complex even in established war thinking. Take, for example, the sinking of the Argentinian light cruiser ARA General Belgrano in the Falklands crisis in 1982 (Rice and Gavshon 1984). The Belgrano was in international waters, sailing away from the Falkland Islands when it was torpedoed by HMS Galahad. From a tactical perspective the Belgrano posed no threat and so the sinking of the largest ship in the Argentine Navy appears to have been a disproportionate action, especially considering the 3000 lives that were lost when the ship sank. Yet from a strategic perspective, the Belgrano was able to protect the rest of the Argentine fleet from the British Navy. With the removal of this battleship, the British Navy was able to dominate the waters around the Falkland Islands, strengthening the British military presence significantly (Rice and 
Gavshon 1984, 115-31). Hence we might say that the sinking of the Belgrano was disproportionate from a tactical perspective but proportionate from a strategic perspective.

If there are such challenges within traditional war discourse when it comes to determining proportionality, how much more difficult is this when thinking about new technologies used in intelligence? The challenge here is that the condition of proportionality frequently lacks sufficient granularity to be able to determine what is and is not a proportionate action in intelligence. We are therefore challenged to come out with ethical guidance in the face of a very broad brush framework. There are further problems in applying the just war tradition to intelligence, not least that the just war tradition is a predominantly Western tradition, rooted in a combination of classical philosophy and Judaeo-Christian ethics. As such, one wonders how such ethical precepts might be applied on a global level. There have been attempts to develop a truly global ethics in recent years, catalyzed by the international aspect of the internet and globalization (Brey 2007; Ess 2008; 2006; Küng and Kuschel 1993; Widdows 2014; 2016). While these concerns are hardly new in thinking about military ethics (we have, after all, experienced two world wars in the last 120 years) they do leave open concerns that what appears proportionate to western values may not appear to be proportionate when one's starting point is Buddhist or Taoist ethics.

Finally, there is the concern of the Collingridge dilemma (Kudina and Verbeek 2019; Liebert and Schmidt 2010). This states that we have an essential problem in determining the ethics of new and emerging technologies. We frequently do not know what the ethical problems with new technologies will be until those technologies have become embedded in society. The dilemma then arises because when the technology has been fully embedded in society, it is too late to restrict or even prevent the distribution of that technology. There have been several suggestions as to how to approach ethics of emerging technology, ${ }^{1}$ but the problem remains that we will always be left in a position of some uncertainty as to the ethical implications of new technologies prior to their actual use in society.

If we bring these three concerns together (the lack of granularity in determining proportionality, the varying ethical assumptions across the globe and the empirical uncertainties of new technologies) then we discover some significant gaps in the application of just war thinking to intelligence ethics insofar as this concerns new and emerging technologies. In the face of these gaps I want to propose that a practical way forward is to consider what we believe will be the likely response of the spied upon party upon discovery of a particular act of espionage. This would fall within the traditional jus in intelligentia category of considering likely consequences without necessarily being consequentialist (Hurka 2005; Macnish 2016 ; 2015). Furthermore, my proposal is not that we determine our action on the basis of a likely response, but rather that we determine our tolerance threshold for such responses. That is, we should determine our behaviour on the basis of what we may reasonably trigger by our actions. Note that this is not a condition of reciprocity through which we may find that we are drawn into a vicious cycle of being forced to conduct unethical acts because our adversaries have committed 
those acts. Rather, it is a matter of asking whether it is acceptable for us to do $\mathrm{X}$ if we have reasonable grounds to believe that $\mathrm{X}$ will trigger $\mathrm{Y}$.

For example, if the act of arresting an intelligence officer from an adversarial state is reasonably believed to occasion a declaration of war from that state, then we may determine that the arrest of said officer would be a disproportionate act. If, on the other hand, the arrest is likely to occasion a reciprocal arrest of one of our intelligence officers in that state, then the act might well fall within our tolerance threshold of a reasonable price to pay for the action. At the same time, the context might be such in which the declaration of war may be appropriate for other reasons (and hence fall within our tolerance threshold), or indeed in which the arrest of one of our intelligence officers would fall outside our tolerance threshold. In the remainder of this chapter I will develop this thought of considering tolerance thresholds to the risky application of new technologies in intelligence (and specifically, cyber intelligence).

\section{Cyber intelligence and digital sleeper cells}

We may distinguish between security, counterintelligence and intelligence through a lens of active versus passive approaches to state security and economic wellbeing. Security is a matter of preventing attacks or espionage against the state through relatively passive means, while counterintelligence involves preventing attacks or espionage against the state through more active measures designed to reveal the intentions and abilities of adversaries. Intelligence itself is then about attacking adversaries in order to gather intelligence on their intentions and abilities. More kinetic active approaches such as agents provocateurs and sabotage, while not forming a part of intelligence collection in a strict sense, frequently fall within the purview of state intelligence agencies. That is, they are not, at least in times of peace, the appropriate domain for military action but are rather managed by state intelligence.

A similar continuum can be drawn when it comes to the online connected world of cyber. Cyber security is relatively passive, seeking to prevent attacks and espionage through the use of firewalls, monitoring and the development of highly secure systems. Cyber counterintelligence is the more active state of preventing attacks and espionage through the active gathering of intelligence about the terrorist or espionage intentions of adversaries. Cyber intelligence is therefore focused on attacking adversaries in order to gain intelligence on their broader intentions and abilities insofar as these have a bearing on the state. Acts of cyber sabotage, fake news generation and similar cyber activities once more fall beyond the traditional understanding of intelligence and yet are not clearly military activities when enacted during peacetime. As with the physical analogues of agents provocateur and sabotage, acts of cyber sabotage and active disinformation campaigns interfering with domestic activities of adversarial states are typically managed by state intelligence agencies.

One particular approach to cyber sabotage and cyber intelligence gathering is that of a digital sleeper cell. This is a form of malware which is inserted into 
an adversary's computer network but which remains dormant until activated at some point in the future. The analogy is drawn with a sleeper cell in terms of intelligence collection, for instance when agents are inserted into a foreign country and live as regular citizens in that country for years, building networks of trust and allowing them to rise to positions of significance and importance before becoming active and returning information to their country of origin (Leuprecht, Szeman, and Skillicorn 2019). This is an approach which has reportedly been employed by China in infiltrating a number of US economic interests over the last 20 to 30 years as a means of gathering intellectual property on key technological developments (Fialka 1999, 18-40).

The digital sleeper cell is therefore distinct from more traditional forms of cyberattack such as worms, Trojan horses and phishing attacks. A digital sleeper cell may be used to insert one of these traditional forms of malware, but only when the sleeper cell is activated. Hence the Stuxnet virus developed by Israel and the United States and employed against the Iranian nuclear power system in 2011 was a virus which brought down that system but was not a digital sleeper cell as it became active as soon as it was placed in the system (Farwell and Rohozinski 2011; Langner 2011). Similarly, the WannaCry and notPetya attacks of more recent years were straightforward cyberattacks (Greenberg 2018; Marsh 2018; Mattei 2017; Mohurle and Patil 2017; Smart 2018). By contrast, the Black Energy virus used against the power grid in the Ivano-Frankivsk region of Ukraine in 2014 involved the use of a digital sleeper cell. In this case, the virus had lain dormant in the system for some time before it was triggered by various people, themselves subject to a spear phishing attack, clicking on macros in Microsoft Excel files (Lehman 2016).

Digital sleeper cells do not have to be used solely for the purpose of sabotage. They may, for instance, also be used in intelligence gathering activities. Such a cell may be inserted into a country's network but once more will remain dormant until active, at which point it will start returning information to the initiating organization. In the case of intelligence collection it is perhaps harder to see why one would not wish to begin the intelligence collection immediately. It may be the case that one wishes to have the potential for intelligence collection on a certain network without having the need or perhaps the capacity to deal with the intelligence that the network would reveal in the short term. However, the discovery of such a digital sleeper cell would likely occasion a similar response to the finding of an active intelligence gathering cyberattack. By contrast, a digital sleeper cell aimed at sabotage, if discovered, might occasion a less extreme response than the act of sabotage itself. The discovery of a digital sleeper cell is hence similar to the discovery of a "real threat". One may know in principle that there is a threat (what we may call a "mere threat"), but the discovery of actual means in place to enact the threat elevates it to a "real threat". A "real threat" poses a greater risk to the state than a "mere threat", but not as much risk as it would were the threat to be enacted. There are hence three levels of concern: "mere threats", "real threats" and "enacted threats". As these increase in terms of harm (from potential to actual), the severity of response is likely to increase also. 


\section{Kevin Macnish}

It is also worth noting that digital sleeper cells may or may not be anonymous. In the analogue equivalent of an espionage sleeper cell, the agents in that cell would not wish to reveal the intentions of the sending organization (i.e. that they are present purely for the purposes of economic espionage for their sending country). In the case of the digital sleeper cell, though, it may be that the sending organization desires that it is recognized as such after the act of sabotage has occurred. Through this, the sending organization might gain kudos within the intelligence community, gain the advantage of fear over adversaries and potential adversaries and show off to its political bosses about the efficacy of its operations. This was the case with the Black energy digital sleeper cell in Ukraine around which there seems to have been no question but that it had been developed and put in place by Russian intelligence (Lehman 2016).

It is therefore the task of state cyber security agencies to protect against the insertion of digital sleeper cells into sensitive state networks. These agencies are typically tasked also with the counterintelligence activity of locating digital sleeper cells, and frequently also with the development and placing of digital sleeper cells themselves in adversarial networks. As such, digital sleeper cells are becoming an active and pervasive means of low-level cyber conflict, a "real threat" within a domestic networked infrastructure. A key ethical concern with the use of digital sleeper cells, though, is that we do not know how they will be received upon discovery by the recipient state (Leuprecht, Szeman, and Skillicorn 2019). I have suggested, for example, that the discovery of a digital sleeper cell with the goal of triggering an act of sabotage might occasion a lesser response than the act of sabotage itself. However, this is not a given. It may well be that the recipient state chooses to interpret the presence of a sabotage-related digital sleeper cell as tantamount to the act of sabotage that it threatens. As Leuprecht at al. note:

because of the widespread lack of understanding of the operation of cyber and cyberphysical systems, the difficulty of distinguishing malice from incompetence when communication and computation systems malfunction, and the difficulty of assessing intent, the targets of [digital sleeper cells and other offensive threats] cannot easily judge the magnitude of the threat. There is at least the possibility that they will overreact, perhaps extremely. This could lead to retaliation at higher levels and so escalation, perhaps even spilling over into kinetic responses.

(Leuprecht, Szeman, and Skillicorn 2019, 400-1)

In this way, we are returned to the three problems raised earlier regarding the use of the just war framework for determining ethical actions in cyberspace. There is a lack of granularity in terms of determining whether a digital sleeper cell would be proportionate, based in part upon a lack of knowledge as to how the sleeper cell would be perceived by the recipient state and the challenge of the Collingridge dilemma that we will not know for certain the impact of the digital sleeper cell until it is activated. 
For example, imagine that South Korea places a digital sleeper cell on a North Korean network. In this case, context is crucial. The likely North Korean response would probably differ depending on whether the network related to the Ministry of Defence, a munitions factory, a power network or a hospital. It seems that there are a number of potential responses that North Korea could take in this situation. It might decide that digital sleeper cells are what it does as well and therefore not worry overly about the situation. It might believe that its own digital sleeper cells are not obvious to the South Korean security services and try to gain diplomatic advantages by touting the cyber infiltration performed by South Korea in the international community. A third alternative is that the North Korean state could interpret the presence of the digital sleeper cell as a "real threat" against the target. A fourth alternative would be that the digital sleeper cell is seen as an attack on the target. Lastly, and the most extreme, would be to see the digital sleeper cell as an attack on the state itself. This might appear to be an extreme response. After all, it is tragic for a hospital to experience a cyberattack in the way that many British hospitals suffered through the WannaCry attack in 2017 , but this was not seen as an attack on the state. However, it is not unfeasible to think of a scenario in which a liberal democracy employs digital voting software for a national election only to find such software has been infiltrated by a digital sleeper cell which threatens to sabotage the process by altering votes for particular candidates. In this latter case the attack may be seen as tantamount to one on the democratic foundations of the liberal state. Such an attack might then quite reasonably be interpreted as casus belli and lead to a kinetic military response (Smith 2018).

Furthermore, even thinking in these terms assumes a very high degree of knowledge regarding the recipient state's networks and the potential for damage of whatever malware the digital sleeper cell will enact. It is worth remembering that the first worm was created in what was believed to be a secure networked environment of university computers by graduate student Robert Tappan Morris in 1988 (Branscomb 1990). What that student did not know was that at least one of the computers was attached to the broader network of computers linking universities at the time, leading to an FBI investigation. In a similar manner, it is not implausible that a Ministry of Defence computer network might at some point connect to a civilian hospital network, allowing any attack on the legitimate defence target to spread to a non-legitimate civilian target. In this way, the digital sleeper cell would form a part of an indiscriminate act of targeting, thus violating the principle of discrimination in the just war tradition.

The use of digital sleeper cells therefore raises a number of ethical issues from the outset. As Donald Rumsfeld once famously said in relation to the Iraq War, there are known unknowns and unknown unknowns (Daase and Kessler 2007; Pawson, Wong, and Owen 2011). In this case, the known unknowns include the likely response of the recipient state upon discovery of a digital sleeper cell. The unknown unknowns here involve the precise spread and impact of whatever malware the digital sleeper cell unleashes. 


\section{Kevin Macnish}

\section{Cyber intelligence, ethics and risk}

I have argued elsewhere that we should understand security as the inverse of risk. That is, the greater the things we value are put at risk (in terms of greater probability of harm, or greater harm), the less secure the situation in which we find ourselves and vice versa. Given the aforementioned continuum between security, counterintelligence and intelligence, intelligence activities (including sabotage) can reasonably be seen as acts of risk management in the national security and intelligence sphere. Cyber security (and, by extension, cyber counterintelligence and cyber intelligence) is a subcategory of this way of thinking. Cyber security is therefore a measure of risk insofar as that risk occurs in relation to the cyber domain, and cyber intelligence is a matter of risk management wherever intelligence and related activities take place in relation to the cyber domain. Of course, it is increasingly the case that for much of the world everything of significance is at least impacted by, if not reliant on, the cyber domain. As this tendency increases it will become less relevant to discuss "cyber" security and simply refer to "security". Put another way, the context of security will likely soon be such that the vast majority of security is in some manner a matter of cybersecurity.

The benefit of defining security and intelligence in terms of risk is that this opens to discussion a vast discourse on the ethics of risk, which has been developed over the last 30 years by academics such as Sven Ove Hansson. The definition places risk as the central concern of intelligence and security activities, which in turn challenges us to think more carefully about what is meant by and what is implied by situations involving risk.

A standard definition of risk would involve a calculation of severity and probability. The more severe the harms which are threatened in a risky situation, the more risky that situation will be. Similarly, the greater the likelihood of harms occurring renders a risky situation more risky. Hence a low probability of a minor paper cut is a low risk. The high probability of losing one's life is, by contrast, a high risk. There are then any number of intermediate positions involving the high probability of a minor harm (a high likelihood of a paper cut, for example) and a low probability of a major harm (a remote chance of death).

Through breaking down risk into its constituent terms of severity and probability we are then more able to see which ethical issues may arise through engagement in risky situations such as the placing of digital sleeper cells in conditions of epistemic uncertainty. For example, I have already suggested that we do not know what harm may arise through the employment of a digital sleeper cell in at least some contexts. We may have a reasonable idea as to what would happen if the digital sleeper cell were activated, although even then there is the problem of unforeseen network connections allowing for malware to travel between legitimate and illegitimate targets, but there is also the question as to what would happen if the digital sleeper cell were discovered before being activated. We are once more in the realm of the unknown unknowns in the cyber domain. Hence the calculation of (likely) harms is extremely complex, if not impossible. 
Furthermore, there are additional problems in terms of the subjectivity of harm. Generally speaking, harms have both objective and subjective dimensions. It is, ceteris paribus, undoubtedly objectively harmful for a person to lose their hand. However, it is arguably worse for a concert pianist to lose her hand than for a philosopher to lose his. This may be exaggerated when it comes to harms arising to people of different cultures and societies. This was brought home to many in a recent Massachusetts Institute of Technology (MIT) experiment involving selfdriving vehicles (Awad 2017; Ganesh 2017; Holstein and Dodig-Crnkovic 2018). Most research subjects in Europe and the United States, when placed in a dilemma in which a self-driving car needed to kill one of a number of people, opted for the car to kill an elderly person rather than a child. This was reversed when the same experiment was conducted with Chinese research subjects. There may be a number of reasons for this, not least a traditional reverence for the elderly in China, which has been absent from European and American culture for some time and issues of overpopulation in China, whereas many countries in Europe are experiencing population decline. The fact remains, though, that the harm of killing a child vis-à-vis the harm of killing an elderly person in at least this one scenario differed from a subjective perspective depending on whether the person asked was Chinese or European. As such, it is extremely difficult to measure the harms which might arise as a result of employing a digital sleeper cell in a state with radically different values from one's own.

There are further questions to be asked about the distribution of risk. It is frequently the case that the person making a risky decision will not be the same person who faces paying the costs of that decision (Wolff 2010). If I choose to go hang gliding, and sufficiently inform myself of the risks implicit in that, then I freely undertake to both experience the benefits of hang gliding (the joy of soaring through the air) and the costs of hang gliding (the chance of something going wrong leading to a fatal accident). This, though, is a very different situation from one in which I determine whether you should go hang gliding, in which case I make the decision while you bear the costs and benefits. Yet another alternative may be a situation in which I make a decision from which I stand to benefit but you stand to pay the costs. Such was the case, for example, when Ford decided not to recall their Pinto model in the 1970s even after the car was determined to be unsafe on the roads (Lütge 2018; Malloy and Lang 1993). In that instance, the senior management of Ford were almost certainly neither driving a Pinto themselves, nor were they making the information about the lack of safety of the Pinto available to the general public. The decision makers were therefore benefiting from the decision in terms of salaries arising from sales of the Pinto model (coupled with savings on not conducting a recall) while the general public, both drivers and passengers in Pinto cars and those on the road with them, stood to pay the costs arising from having unsafe vehicles on the roads. In the case of digital sleeper cells, we are almost certainly talking about a scenario far closer to that of the Ford Pinto than of my going hang gliding. The digital sleeper cell is put in place by one state which stands to benefit from the activation of that cell at some point in the future, while the recipient state gains nothing but bears the cost of any 


\section{6}

sabotage that may occur. This distribution of the risk in using sleeper cells renders them, in and of themselves, a highly attractive approach to intelligence activities. The way in which that risk is balanced out is through the threat of reciprocal action on the part of the recipient state. However, as noted earlier, we frequently do not know what that reciprocal action will be and therefore are left in a position of uncertainty.

While these are relatively broad problems which come from looking at the ethics of risk, there are a number of very specific problems which occur in debates surrounding risky situations on a frequent basis and are nonetheless fallacious. These have been highlighted as fallacies of risk by Sven Ove Hansson (Hansson 2004). Of these, at least three seem to pertain particularly to problems in cyber intelligence and digital sleeper cells. The first is what Hanson calls the tuxedo fallacy (Hansson 2009, 426). This is essentially a critique that calculations of risk are often undertaken under conditions of extreme simplification, in the process of which complicating but important externalities are ignored. In this way, risk can be calculated with a seemingly mathematical certainty, just as one can be sure of the 1 in 38 probability of the ball on a roulette wheel landing on any particular number. However, Hanson's point is that quite clearly in real life we are not able to calculate probabilities with anything like the level of accuracy that we are in an ideal casino. We may be able to talk of more or less probability of a particular event occurring, but in many cases, it is relatively meaningless to talk of a $56 \%$ chance versus a $62 \%$ chance of a particular event unfolding. As such, we can talk about likelihoods in terms of particular states responding to the discovery of a digital sleeper cell within a network, but it is hard to say that the risk of placing a digital sleeper cell in the network pertaining to a Ministry of Defence, for example, would be numerically greater than the risk of placing the same digital sleeper cell in the network of the same state's Ministry of Foreign Affairs.

A second fallacy that Hanson raises is what he calls the "sheer size fallacy" (Hansson 2004, 353). This fallacy holds that if a prospective risk appears to be smaller than a currently accepted risk then the prospective risk is worth taking. There are several problems with this position, not least that the currently accepted risk might actually be unacceptably large but not recognized as such. For example, it is frequently argued that the risk of accidents occurring with self-driving vehicles is lower than the risk of accidents occurring with manually driven vehicles. The conclusion of this line of argument is therefore we have an imperative to get self-driving vehicles on the roads as soon as possible. While this may be true, it may also be the case that the risks of driving both manual and self-driving vehicles could be too high (i.e. above a threshold of acceptability to the majority in society). It also obscures the potential to reduce the risk self-driving vehicles further, permitting one to settle for a mere improvement on risk rather than seeking to achieve a significant or substantial improvement. The parallel here with digital sleeper cells is their apparently low-risk nature. Without considering potential or likely retaliatory measures, as suggested here, a digital sleeper cell appears attractive given that no agents' lives are risked and the potential for devastation is significant. 
The third fallacy to consider here is what Hansson calls the "infallibility fallacy" (Hansson 2004, 359). This arises when experts and the public have differing attitudes to a course of action, leading to the conclusion that the public are wrong about the right course of action. The response of those guilty of the fallacy is typically that the public need to be better informed in order to come to the "right" conclusion. However, as Hansson points out, it may also be that the experts are wrong (as they have been on many occasions). He notes that

when the output of a risk analysis of a complex technology indicates a low level of risk, the possibility that this analysis was wrong may very well be a dominant part of the legitimate concerns that a rational decision maker can and should have with respect to the technology in question.

(Hansson 2004, 359)

In the case of intelligence activities, it is rare that the general public becomes aware of operations until 30 years or more after the event, unless there is a scandal. Rather than running all potential intelligence activities past the public for comment (even in the abstract), the "public" in intelligence cases is typically, at least in liberal democracies, represented by parliamentarians in committees that oversee the intelligence agencies. In this case, the fallacy would unfold as parliamentarians expressing concerns about a particular course of action (the use of digital sleeper cells either in the abstract or in a particular instance) and being told by the heads of the respective intelligence agencies (in this case, the experts) that they are simply wrong.

There is already a general lack of expertise in intelligence matters, which may be compounded by a tendency to hold the intelligence agencies somewhat in awe. This is then further compounded by a lack of expertise in cybersecurity (quite possibly shared by the head of the intelligence agency), which means they are likely to be swayed in favour of accepting operations proposed by the experts. Due to the composition of the accountability process, there is unlikely to be strong evidence to the contrary of what is being proposed, leading to an assumption that, as the fallacy states, the experts are right and the politicians wrong. This could once more lead to a more risk-prone scenario.

As Hansson notes, this fallacy can be overcome to some degree through education and politicians (and others) with oversight of intelligence activities have a duty to become as informed as possible within any reasonable confines of national security considerations. However, the responsibility does not (should not) lie with politicians alone, but with the intelligence agencies to present the alternatives as clearly and impartially as possible with the aim not of winning an agenda but of gaining a clear sense of direction from political masters. Furthermore, the mere awareness of the fallacy's existence is a first step to countering its effects.

In summary, there are a number of benefits of seeing cybersecurity in terms of risk, not least in being able to draw on a growing body of literature dedicated to discussing the ethics of risk. Some of the challenges raised here in relation to digital sleeper cells have been problems of epistemic uncertainty, subjective elements 


\section{Kevin Macnish}

in calculating harms and the distribution of risk costs and benefits. In addition, there are at least three fallacies that Hansson suggests in relation to risk which have application to the deployment of digital sleeper cells and cyber intelligence in general. The three on which this chapter has focused have been the tuxedo fallacy, the sheer size fallacy and the infallibility fallacy. Each of these can have a significant impact on how risk is calculated and determined to be acceptable or not.

It is, once more, important to be clear that in raising these issues I am not directing criticism at any one state or intelligence agency, still less any individual. To the best of my knowledge, most western liberal democracies have accountability structures surrounding their intelligence agencies of varying degrees of robustness. Furthermore, those who reach significant positions of authority within those agencies tend to be conservative and risk-averse, often far more so than their political masters. ${ }^{2}$ Nonetheless, while this is currently the case, it would be foolish to rely entirely on internal cultures of conservatism to ensure that only those who were generally risk-averse became the key decision makers in these organizations.

\section{Conclusion and call to action}

The realm of cyber intelligence, just as the realm of cyber security, is introducing new technologies and new techniques which carry ethical consequences. While we have developed ethical frameworks for approaching intelligence, my argument in this chapter has been that these frameworks, and particularly the just war tradition on which I have focused, lack the degree of granularity necessary for determining whether these new technologies are ethically acceptable in their application. In response to this, I suggested that we may add a consideration within the proportionality principle of jus in intelligentium to the effect that we consider the proportionality of a particular intelligence technique through the lens of the likely response that this technique will occasion if discovered by an adversary.

This approach is both plausible and helpful in determining at least one set of likely outcomes from the use of a new technology in intelligence. At the same time, the focus on the need to determine an adversary's reaction highlights how little we may know about the likelihood of that reaction. In many cases, we are operating blindfolded in a dark room, exacerbated by differences in ethical values on a global scale and a lack of knowledge sufficient to provide certainty as to the full extent of the potential damage of any malware inserted into a network by a digital sleeper cell.

I have also argued that intelligence and security are areas which involve risk management, which, as we have seen, introduces further ethical complications in terms of the determination of risk, its distribution and a number of fallacies which are frequently associated with it. Through approaching intelligence situations with the ethics of risk in mind, we may be better able to at the very least avoid or mitigate some of these fallacies and at the same time recognize the shortcomings of our own rational beliefs.

Ultimately, my concern in this chapter has been that if we compensate for a lack of granularity in, for example, proportionality conditions through determining 
likely responses to the implementation of new technologies such as digital sleeper cells, then we will be confronted with our own significant epistemic uncertainties. There are, of course, means to respond to such uncertainties. The most obvious is perhaps that of international law. However, international law is itself at times very vague, and, like all laws, frequently lags behind technological innovation. The Tallinn Manual 2.0 has been a valuable contribution to determining the manner in which international law applies to cyber security and cyber intelligence operations between states. Yet Tallinn 2.0 runs into similar problems as the just war tradition. As with the just war tradition, it is at times insufficiently granular to provide clear guidance on the employment of novel technologies. The manual also evidences a lack of agreement between experts on key issues of applying international law to the cyber realm. Finally, as the manual itself makes clear in the introduction, it is no more than the views of a limited group of experts. The Tallinn Manual 2.0 is not legally binding and is intended as the start of the conversation rather than its conclusion.

Instead of encouraging further international law around cyber intelligence activities, more effort should therefore be placed into informal bilateral and multilateral agreements between operators. ${ }^{3}$ As Leuprecht et al. note,

there is an opportunity to constrain and shape the way that states engage in cyberwarfare in the future in the way the Law of Armed Conflict, the UN Charter, and the UN Declaration of Human Rights have done in the kinetic realm.

(Leuprecht, Szeman, and Skillicorn 2019)

While such informal agreements as I am proposing may lack the compelling nature of international law, through their informal nature, they can allow for respective intelligence agencies to be more open about what they do and do not wish to see happen as a result of cyber activities.

\section{Notes}

1 See for example Boenink, Swierstra, and Stemerding (2010), Brey (2017; 2012; 2011), Lucivero, Swierstra, and Boenink (2011), Palm and Hansson (2006) and Wright (2011).

2 One may think here of the reported instance when the then British Prime Minister asked his intelligence chiefs if they couldn't just assassinate Idi Amin, the Ugandan dictator. The response was said to be a polite, "We don't do that sort of thing". If that is genuinely reported then it reflects well, but is clearly not universal, as the CIA evidently were actively engaged in assassination attempts in the 1960s viz. at least Fidel Castro and Patrice Lumumba (Johnson 1992).

3 See for example Meyer (2011). Also see OSCE, Decision 1202 OSCE ConfidenceBuilding Measures to Reduce the Risks of Conflict Stemming from the Use of Information and Communication Technologies, PC.DEC/1202 (March 10, 2016); United Nations, General Assembly, Group of governmental experts on developments in the field of information and telecommunications in the context of international security, A/70/150 (July 22, 2015); UN General Assembly, Resolution adopted by the General Assembly, Training 23, 1 (December 19, 2014). 


\section{References}

Awad, Edmond. 2017. "Moral Machines: Perception of Moral Judgment Made by Machines". PhD diss., Massachusetts Institute of Technology. https://dspace.mit.edu/ handle/1721.1/112532.

Bellaby, Ross W. 2014. The Ethics of Intelligence: A New Framework. London; New York: Routledge.

Boenink, Marianne, Tsjalling Swierstra, and Dirk Stemerding. 2010. "Anticipating the Interaction between Technology and Morality: A Techno-Ethical Scenario Study of Experimenting with Humans in Bionanotechnology". Studies in Ethics, Law, and Technology 4 (2): 1-38. https://doi.org/10.2202/1941-6008.1098.

Branscomb, Anne W. 1990. "Rogue Computer Programs and Computer Rogues: Tailoring the Punishment to Fit the Crime". Rutgers Computer \& Technology Law Journal 16: 1.

Brey, Philip. 2007. "Is Information Ethics Culture-Relative?". International Journal of Technology and Human Interaction (IJTHI) 3 (3): 12-24.

- 2011. "Anticipatory Technology Ethics for Emerging IT". In CEPE 2011: Crossing Boundaries, 13-26. Milwaukee, WI: INSEIT.

_. 2012. "Anticipatory Ethics for Emerging Technologies". NanoEthics 6 (1): 1-13. https://doi.org/10.1007/s11569-012-0141-7.

- 2017. "Ethics of Emerging Technologies". In Ethics of Technology Methods and Approaches, edited by Sven Ove Hansson, 175-91. London; New York: Rowman \& Littlefield Publishers.

Daase, Christopher, and Oliver Kessler. 2007. "Knowns and Unknowns in the 'War on Terror': Uncertainty and the Political Construction of Danger”. Security Dialogue 38 (4): 411-34. https://doi.org/10.1177/0967010607084994.

Ess, Charles. 2006. "Ethical Pluralism and Global Information Ethics". Ethics and Information Technology 8 (4): 215-26. https://doi.org/10.1007/s10676-006-9113-3.

2008. "Culture and Global Networks: Hope for a Global Ethics". In Information Technology and Moral Philosophy, edited by M. J. van den Joven and J. Weckert, 195-225. Cambridge: Cambridge University Press.

Farwell, James P., and Rafal Rohozinski. 2011. "Stuxnet and the Future of Cyber War". Survival 53 (1): 23-40. https://doi.org/10.1080/00396338.2011.555586.

Fialka, John J. 1999. War by Other Means: Economic Espionage in America. New York: W. W. Norton \& Company.

Ganesh, Maya I. 2017. "Entanglement”. Machine Research 6 (1): 76-87. https://doi.org/ 10.7146/aprja.v6i1.116013.

Greenberg, Andy. 2018. "The Untold Story of NotPetya, the Most Devastating Cyberattack in History". Wired, August 22. www.wired.com/story/notpetya-cyberattackukraine-russia-code-crashed-the-world/.

Hansson, Sven O. 2004. "Fallacies of Risk". Journal of Risk Research 7 (3): 353-60. https://doi.org/10.1080/1366987042000176262.

- 2009. "From the Casino to the Jungle". Synthese 168 (3): 423-32. https://doi. org/10.1007/s11229-008-9444-1.

Herring, Eric, and Piers Robinson. 2014. "Deception and Britain's Road to War in Iraq". International Journal of Contemporary Iraqi Studies 8 (2-3): 213-32. https://doi. org/10.1386/ijcis.8.2-3.213_1.

Holstein, Tobias, and Gordana Dodig-Crnkovic. 2018. "Avoiding the Intrinsic Unfairness of the Trolley Problem". In Proceedings of the International Workshop on Software Fairness, 32-7. FairWare '18. New York, NY: Association for Computing Machinery. https://doi.org/10.1145/3194770.3194772. 
Humphreys, James. 2005. "The Iraq Dossier and the Meaning of Spin". Parliamentary Affairs 58 (1): 156-70. https://doi.org/10.1093/pa/gsi013.

Hurka, Thomas. 2005. "Proportionality in the Morality of War". Philosophy \& Public Affairs 33 (1): 34-66. https://doi.org/10.1111/j.1088-4963.2005.00024.x.

Johnson, Boyd. 1992. "Executive Order 12,333: The Permissibility of an American Assassination of a Foreign Leader". Cornell International Law Journal 25 (2): 401-36.

Kudina, Olya, and Peter-Paul Verbeek. 2019. "Ethics from Within: Google Glass, the Collingridge Dilemma, and the Mediated Value of Privacy". Science, Technology, \& Human Values 44 (2): 291-314. https://doi.org/10.1177/0162243918793711.

Küng, Hans, and Karl-Josef Kuschel. 1993. A Global Ethic: The Declaration of the Parliament of the World's Religions. New York: Continuum.

Langner, Ralph. 2011. "Stuxnet: Dissecting a Cyberwarfare Weapon”. IEEE Security Privacy 9 (3): 49-51. https://doi.org/10.1109/MSP.2011.67.

Lehman, Gary. 2016. "Cyber-Attack against Ukrainian Power Plants Prykarpattyaoblenergo and Kyivoblenergo: Lessons Learned; Implementation Considered". https:// garylehman.net/wp-content/uploads/2016/01/Cyber-Attack-Against-Ukrainian-PowerGrid-Implications.pdf.

Leuprecht, Christian, Joseph Szeman, and David B. Skillicorn. 2019. "The Damoclean Sword of Offensive Cyber: Policy Uncertainty and Collective Insecurity". Contemporary Security Policy 40 (3): 382-407. https://doi.org/10.1080/13523260.2019.1590960.

Liebert, Wolfgang, and Jan C. Schmidt. 2010. "Collingridge's Dilemma and Technoscience”. Poiesis \& Praxis 7 (1): 55-71. https://doi.org/10.1007/s10202-010-0078-2.

Lucivero, Federica, Tsjalling Swierstra, and Marianne Boenink. 2011. "Assessing Expectations: Towards a Toolbox for an Ethics of Emerging Technologies". Nanoethics 5 (2): 129-41. https://doi.org/10.1007/s11569-011-0119-x.

Lütge, Christoph. 2018. Ford Pinto: Is Cost-Benefit Analysis Allowed in Ethical Decision Making? London: SAGE. https://doi.org/10.4135/9781526442093.

Macnish, Kevin. 2015. "An Eye for an Eye: Proportionality and Surveillance". Ethical Theory and Moral Practice 18 (3): 529-48. https://doi.org/10.1007/s10677-0149537-5.

2016. "Persons, Personhood and Proportionality: Building on a Just War Approach to Intelligence Ethics". In Ethics and the Future of Spying: Technology, National Security and Intelligence Collection, edited by Jai Gaillott and Warren Reed, 95-106. Abingdon, UK: Routledge.

. 2017. The Ethics of Surveillance: An Introduction. London; New York: Routledge.

Malloy, David C., and Donald L. Lang. 1993. "An Aristotelian Approach to Case Study Analysis". Journal of Business Ethics 12 (7): 511-16. https://doi.org/10.1007/ BF00872372.

Marsh, Sarah. 2018. "US Joins UK in Blaming Russia for NotPetya Cyber-Attack". The Guardian, February 15. www.theguardian.com/technology/2018/feb/15/uk-blamesrussia-notpetya-cyber-attack-ukraine.

Mattei, Tobias A. 2017. "Privacy, Confidentiality, and Security of Health Care Information: Lessons from the Recent WannaCry Cyberattack". World Neurosurgery 104 (August): 972-4. https://doi.org/10.1016/j.wneu.2017.06.104.

Meyer, Paul. 2011. "Cyber-Security through Arms Control”. The RUSI Journal 156 (2): 22-7. https://doi.org/10.1080/03071847.2011.576471.

Mohurle, Savita, and Manisha Patil. 2017. "A Brief Study of Wannacry Threat: Ransomware Attack 2017”. International Journal of Advanced Research in Computer Science 8 (5): 1938-40. https://doi.org/10.26483/ijarcs.v8i5.4021.

Omand, David. 2011. Securing the State. London: C. Hurst \& Co Publishers Ltd. 


\section{Kevin Macnish}

Palm, Elin, and Sven O. Hansson. 2006. "The Case for Ethical Technology Assessment (ETA)”. Technological Forecasting and Social Change 73 (5): 543-58. https://doi. org/10.1016/j.techfore.2005.06.002.

Pawson, Ray, Geoff Wong, and Lesley Owen. 2011. "Known Knowns, Known Unknowns, Unknown Unknowns: The Predicament of Evidence-Based Policy”. American Journal of Evaluation 32 (4): 518-46. https://doi.org/10.1177/1098214011403831.

Quinlan, Michael. 2007. "Just Intelligence: Prolegomena to an Ethical Theory". Intelligence and National Security 22 (1): 1-13. https://doi.org/10.1080/02684520701200715.

Rice, Desmond, and Arthur Gavshon. 1984. The Sinking of the 'Belgrano'. London: Martin Secker \& Warburg Ltd.

Smart, William. 2018. Lessons Learned Review of the WannaCry Ransomware Cyber Attack. London: NHS.

Smith, Patrick T. 2018. "Cyberattacks as Casus Belli: A Sovereignty-Based Account". Journal of Applied Philosophy 35 (2): 222-41. https://doi.org/10.1111/japp.12169.

Widdows, Heather. 2014. Global Ethics: An Introduction. Abingdon, UK: Routledge. https://doi.org/10.4324/9781315711379.

. 2016. "Why and What Global Ethics?". In Ethics in an Era of Globalization, edited by M. S. Ronald Commers, Wim Vanderkerckhove, and An Verlinden. 1st edition, 95-112. London; New York: Routledge.

Wolff, Jonathan. 2010. "Five Types of Risky Situation". Law, Innovation and Technology 2 (2): 151-63. https://doi.org/10.5235/175799610794046177.

Wright, David. 2011. "A Framework for the Ethical Impact Assessment of Information Technology". Ethics and Information Technology 13 (3): 199-226. https://doi. org/10.1007/s10676-010-9242-6. 